\title{
Introduction to IIPF 2019 special issue in ITAX
}

\author{
Bas Jacobs ${ }^{1} \cdot$ Daniel Waldenström ${ }^{2}$
}

Accepted: 13 February 2021 / Published online: 17 March 2021

(c) The Author(s) 2021

This special issue of International Tax and Public Finance consists of a number of contributions from the 373 papers presented at the 75th Annual Congress of the International Institute of Public Finance (IIPF), which was hosted by the University of Glasgow on August 21-23, 2019, in Glasgow, Scotland.

The theme of the conference was Taxation and Mobility. Four excellent plenary speakers discussed a variety of topics: Rachel Griffith (University of Manchester and IFS, UK) on "The Distributional and Corrective Implications of Sin Taxes", Nathaniel Hendren (Harvard University) on "Social Mobility and Investments in Children", Jonathan Portes (King's College London) on "Brexit and the UK Economy" and Stefanie Stantcheva (Harvard University) on "Taxation and Innovation". In addition, a plenary session on tax policy was organized, featuring three IIPF fellows and two representatives of the Scottish Government.

Many papers presented at the conference dealt with general research areas in public economics, and the two papers published in this special issue reflect this diversity.

The article by Ana Cabral, Norman Gemmell and Nazila Alinaghi studies income tax evasion among the self-employed by using a unique dataset in which household surveys are matched with administrative and tax registers in New Zealand. Their analysis departs from the popular expenditure approach to estimating tax evasion of the selfemployed. A critical assumption underlying that approach is that survey respondents report their income in the same way in the survey as they do to the tax authority. The authors convincingly show that this is not true; taxpayers underreport more income in

Bas Jacobs

bjacobs@ese.eur.nl

https://personal.eur.nl/bjacobs/

Daniel Waldenström

daniel.waldenstrom@ifn.se

https://sites.google.com/view/danielwaldenstrom

1 Erasmus School of Economics, Tinbergen Institute and CESifo, Erasmus University Rotterdam, PO Box 1738, 3000 DR Rotterdam, The Netherlands

2 Research Institute of Industrial Economics Stockholm, CEPR, CESifo, and IZA, Grevgatan 34, 10215 Stockholm, Sweden 
administrative tax data than in surveys. They find that bias could be as large as one-half of the estimated amount of underreported income, which is a policy-relevant result.

The article by Johannes Blum, Florian Dorn and Axel Heuer studies the question of how political democracy in countries affects the level of health expenditures. This study employs a large cross-country panel data set with 151 developing and developed countries over the years 2000-2015. They measure the main explanatory variable, democracy, in several ways. Their main finding is that democracies have substantially higher public health expenditures relative to autocratic regimes. Cross-sectional regressions suggest 20-30\% higher levels and regressions with instrumental variables and panel fixed effects confirm this finding, though with a somewhat smaller positive effect of 10-20\% of democracy on health expenditures. The study's contribution is mainly methodological, by complementing previous studies' cross-sectional evidence with richer results obtained from employing panel data, using more precise measures of democracy, and adopting more robust identification strategies based on instrumental variables and panel fixed effects. The authors conclude that democracies care more for their citizens and aim to reduce inequalities in the access to health care.

The 2019 congress also featured a number of prizes and awards. The 2019 Peggy and Richard Musgrave Prize for the best paper contributed by authors under the age of 40 was awarded to Jonas Löbbing (University of Cologne, Germany) for his paper "Redistributive Income Taxation with Directed Technical Change". The IIPF handed out two Young Economists Awards at the 2019 congress; to Adrian Lerche (Universitat Pompeu Fabra, Spain) for his paper "Investment Tax Credits and the Response of Firms"; and to Mathilde Muñoz (Paris School of Economics, France) for her paper "Do European Top Earners React to Labor Taxation Through Migration?". The 2019 ITAX PhD Student Award, introduced in 2017 by International Tax and Public Finance, has been awarded to Antoine Ferey (Ecole Polytechnique-CREST, France) for the paper "Inattention and the Taxation Bias", co-authored with Jeremy Boccanfuso (Paris School of Economics-EHESS, France). 85 of the papers presented at the Congress applied for the IIPF awards and 67 for the ITAX award.

The 2019 IIPF Congress was a great success and we are grateful to many authors that decided to submit their papers to the IIPF special issue. The publication of the articles in this special issue would not have been possible without the help of the members of the Scientific Committee who initially reviewed hundreds of submissions to the 2019 IIPF Congress. We are grateful to several referees who contributed with their scarce time and valuable advice. We are also thankful for the assistance we received by the editors and staff of International Tax and Public Finance during the publication process. Finally, we would like to express our gratitude to the keynote speakers, the numerous presenters, the discussants of the 75th Annual Congress and, most importantly, the local organizers in Glasgow chaired by Céline Azemar (University of Glasgow). Together, we managed to make the IIPF Congress a memorable event!

Open Access This article is licensed under a Creative Commons Attribution 4.0 International License, which permits use, sharing, adaptation, distribution and reproduction in any medium or format, as long as you give appropriate credit to the original author(s) and the source, provide a link to the Creative 
Commons licence, and indicate if changes were made. The images or other third party material in this article are included in the article's Creative Commons licence, unless indicated otherwise in a credit line to the material. If material is not included in the article's Creative Commons licence and your intended use is not permitted by statutory regulation or exceeds the permitted use, you will need to obtain permission directly from the copyright holder. To view a copy of this licence, visit http://creativecommons.org/ licenses/by/4.0/.

Publisher's Note Springer Nature remains neutral with regard to jurisdictional claims in published maps and institutional affiliations. 